\title{
Transnational labor regulation, reification, and commodification: A critical review
}

\section{George Tsogas ()}

London, UK

Correspondence

George Tsogas, London, UK.

Email: george.tsogas@me.com
Why does scholarship on transnational labor regulation (TLR) consistently fail to search for improvements in working conditions, and instead devotes itself to relentless efforts for identifying administrative processes, semantics, and amalgamations of stakeholders? This article critiques TLR from a pro-worker perspective, through the philosophical work of Georg Lukács, and the concepts of reification and commodification. A set of theoretically grounded criteria is developed and these are applied against selected contemporary cases of TLR. In the totality that is capitalism, reification of social relations of production conceals completely the experiences of workers. In TLR, managerialist and process-oriented scholarship is dominant, verifiable outcomes and positive improvements in conditions of employment are not sought, and worse, meaningless procedures are celebrated as positive achievements.

\section{1 | INTRODUCTION}

More than 11 hundred workers were buried alive and scores of others suffered horrific injuries when the Rana Plaza sweatshop complex collapsed in Bangladesh in April 2013, the biggest loss of life in an industrial "accident" since Bhopal. If such loss of life was the result of a terrorist attack in the United States or Europe, the consequences could have been immense; "coalitions of the willing" could have been formed and military plans put hastily into action. But the response to the Rana Plaza disaster was nowhere near as dramatic. There was a sense of shock as pictures of victims buried in the rubble were circulated in the media, yet "business as usual" quickly prevailed. No candlelight marches were organized in European capitals, politicians did not address the crowds, and no memorials were erected for the victims. A few protested outside department stores, but consumers did not boycott en masse the brands whose labels were found in the ruins of the building. Brands pushed the responsibility for such calamity to subcontractors and delayed paying compensation to victims.

It was not the first time that the deaths of low-wage workers in developing countries who produce want we love to consume made the headlines. In recent years, hundreds if not thousands have 
perished in factory fires, and in social media well-documented stories of sweatshop conditions and child labor are abound. Alas! there has never before been such a hecatomb. It seems that for many it is normal and perfectly natural that "fast fashion" and low-priced goods are widely available, and if thousands of people lose their lives for producing these it is regrettable, but it is not fundamentally a violation of the natural order of things. More "stuff" continuous to be made under the same working conditions as before Rana Plaza, in Bangladesh and elsewhere, and workers, like the fast fashion items they produce, have become commodities that are easily dispensable and disposable.

In this article, we seek to bring to the forefront the workings of capitalism that allow for such commodification to occur; to explain why we are unable to see beyond the form (and the fetishistic appeal) of the commodity and realize the social relations of exploitation that are hidden underneath. In other words, how the human being becomes a mere component of a totalizing capitalist system, where everything becomes commodified, and how the absolute grip that the system exerts on us is such that even massacres such as Rana Plaza fail to produce improvements in the livelihoods of workers (let alone any radical or anticapitalist action extending the democratic control of workers over the workplace and the economy). On the contrary, as we explain, the outcome of Rana Plaza was the production of regimes of labor regulation that, further strengthen capitalist control and normalize exploitation in supply chains.

In that respect, we use TLR as our conceptual laboratory, in as much as it offers us the opportunity to observe and expose the weaknesses and complicity of academic scholarship, government policies and labor market practice. Through direct engagement with the philosophical work of Georg Lukács and the concepts of reification and commodification, we develop a set of normative and substantive criteria that are used to analytically examine TLR from a pro-worker perspective. Specifically, we seek out verifiable improvements in conditions of employment and positive impacts in the everyday work and life of workers are sought, as a result of a TLR intervention.

The article builds on the extensive literature of transnational labor regulation (TLR) in two ways. First, it constructs a critique of TLR from a pro-worker perspective, signaling out managerialist discourses. We observe how (and explain why) scholarship on TLR consistently fails to strive for actual improvements in working conditions and instead devotes itself to relentless efforts for identifying administrative processes, semantics, and amalgamations of stakeholders. Second, the article enhances ongoing debates on TLR and labor standards in supply chains (Coslovsky \& Locke, 2013; Locke, Amengual, \& Mangla, 2009; Rodríguez-Garavito, 2005), by introducing a critical theoretical perspective, which so far has been noticeably absent in literature. TLR is a notoroulsly untheoretical field; it lacks a concrete theoretical perceptive but it is "loaded" with empirical insights and policy perspectives that need the fertile ground of a "big idea" to spread their roots and blossom. Here, we make an attempt to overcome that deficiency by bringing in philosophical enquiry-Marx and Lukács_-to the forefront and connect scholarship on the regulation of labor with philosophy and social theory, resulting in a philosophically and politically informed contribution.

We approach the critique of TLR from a philosophical perspective and draw upon the concepts of commodification, in a classical Marxian standpoint, and of reification, as introduced by Lukács in History and Class Consciousness (1923); engaging with debates from the perspectives of political economy, heterodox economics, labor law, and so on are beyond our purpose and space limitations.

We commence our enquiry by drawing from the Hegelian (come-Marxist) tradition of distinguishing between appearance (form) and essence (Reichelt, 2005). We move beyond appearances and forms of TLR to (re)consider the essence of labor regulation, which rests in the social relations among producers in supply chains. Consequently, we observe at the very outset of our enquiry the existence of a fixation on the "mechanics" of labor regulation (Dehnen \& Pries, 2014), such as the 
nature of the legal language of international treaties, the inclusion criteria and wording of codes of conduct, links between stakeholders, the identification and study of administrative processes, the documentation and dissemination of multi-stakeholder agreements, and various semantics. This focus on form rarely acknowledges social relations of production and hardly penetrates down to how conditions of employment could actually improve, as a result of TLR mediation.

The question that therefore arises is why are often unable to distinguish beyond the level of the form, and remain oblivious to social condition of production in supply chains. In this article, we make an attempt to provide an answer to this challenging question through the concepts of commodification and reification.

Reification ("reification of consciousness [Verdinglichung des Bewußtseins]" has had a profound effect on philosophy, as well as on political, social, critical, and literary theories throughout the 20th century (Bewes, 2002, Chari, 2010, Honneth, Butler, Geuss, Lear, \& Jay, 2008). In sharp contrast, reification has had a limited use in academic discourses of Labor Relations, while direct references to the philosophical context of reification and the work of Lukács are very rare. Hyman (1975) applied the term four times throughout his Industrial Relations: A Marxist Introduction and only in the broad context of warning against ignoring "the real, active men and women whose activities are industrial relations" (p. 31), in favor of suggesting that institutions "possess needs, ambitions and problems" (p. 66). In his analysis of redundancies, Fryer (1973, p. 8) was more revealing and stated that: "by reification is meant the ascription of essentially human characteristics to abstractions or to social structures in such a way as to obscure the fundamental part played by human agencies and human values in social processes." In doing so, "the paradox of reification is that in ascribing human motivations to social processes the very products of human activity are apprehended 'as if they were something other than human products - such as facts of nature, results of cosmic laws, or manifestations of divine will' (Berger \& Luckman, 1971, p. 106), the dictates of a logic of industrialism, or 'the need for the high rate of change demanded by a modern economy' (3). For those who thus reify the social world 'a definite social relation between men ... assumes, in their eyes, the fantastic form of a relation between things' (Marx, 1990, p. 43).”

Distinctively, Tweedie (2013, p. 308) used reification to articulate how "casual work in Australia tends to be conceptualized as a natural category, and thereby implicitly viewed as an illegitimate subject of critique." Further, he showed that Lukács' account of self-reification explains how precarious workers' perceptions of their own status and capabilities are influenced by economic processes, and how casual academic staff perceived themselves as "not a real staff member" (p. 309). Tweedie saw Lukács' work as particularity relevant in explaining the broader discourse of Australian politics, where labor market practices and policies are portrayed as largely being "determined or constrained by autonomous international economic systems" (p. 309) and not by historically specific political and economic choices. Thus, casualization, labor market flexibility, and reforms are taken as normal, common-sense practices that are beyond criticism. Consequently, national neoliberal economic policies were assumed as predetermined and necessitated by international economic circumstances set in motion by "autonomous international economic systems" over which national political elites have no control (p. 309).

Here, we take over the baton to elaborate and broaden the theoretical analysis of TLR through Lukácsian and Marxist philosophy. In Section 1, the theoretical foundations of the Lukácsian thought are laid. That leads in Section 2 to the development of a set of theoretically grounded substantive and normative criteria for assessing TLR from a pro-worker perspective. In Section 3, these criteria are applied against an analytical framework that systematically categorizes historical and contemporary forms of TLR. 


\section{2 | COMMODITY FETISHISM AND REIFICATION}

One of the important contributions that Marx made is the recognition that in capitalism the "mysterious character of the commodity form" (Marx, 1990, p. 164) reflects the social relations that exist among those who worked for the production of commodities. An object becomes a recognizable commodity in capitalism not merely through the quantities of labor-time that were dedicated for its production (a premise introduced by Ricardo), but rather through the recognition of the social relations that existed among those who were involved in its production. In capitalism, commodities are not just "stuff," they are fetishized; people attribute to them almost magical powers that conceal the social relations that make them commodities. Commodity fetishism characterizes a capitalist society as production relations are reified: social relations take the form of relations among things. Lukács (1923) developed further the concept of reification to epitomize the ways in which relations between human beings are disguised in capitalist societies as relations with and even among things. In that sense, a commodity in capitalism is primarily a social form and, according to Lukács, the most basic, fundamental form of a social relationship (here, contra Habermas (1984) and Honneth et al., 2008 we remain faithful to the approach of Lukács that all social relations under capitalism are reified).

Hence, understanding of the commodification process can lead to understanding of the totality of capitalism. In other words, the drive toward commodification, the drive toward profit and generation of surplus value is the principle that animates the totality of the capitalist system. This drive leads to a "perpetually increasing rationalization, to an ever-intensifying exclusion of the qualitative, individual-human characteristics of the worker" (Lukács, 1923, p. 176). The human element is systematically excluded and all human endeavors in capitalism are subjected to a "principle of rationality based on calculation, on calculability" (p. 177) on "quantification of objects" and on their determination by "abstract thought categories" (p. 291), which function as a "reifying and reified integument" (p. 293), concealing reality. Thus, "reification in general, [becomes] a fundamental structural phenomenon of the entirety of bourgeois society" (p. 192). The human being becomes a "number"; "a mechanized component of a mechanical system" (p. 179) and is "broken down...into an element in the movement of commodities" (p. 292). The human being assimilated into this system becomes a "helpless spectator" (p. 180), "a cog in the wheel of economic development" (p. 296). "The human being is objectified as a commodity" (p. 294) and her consciousness becomes "the self-consciousness of the commodity" (p. 295). The longer people experience capitalism, the more profound the permeation of the "structure of reification" into human consciousness becomes (p. 185). Reification gets to be engrained on all interpersonal relations and activities without exception and the individual becomes an object, an anonymous quantity. ${ }^{1}$

\subsection{The totality of capitalism}

According to Lukács, commodification organizes the whole of the society in such a way that is fully and wholly geared toward one and only purpose: the extraction of as much surplus value as possible through profit maximization in any way possible (e.g., through an international division of labor, imperialism, colonialism, increasing efficiency, consolidation of the state to support profit maximization) and of course by crushing all resistance to the process of value extraction.

Lukács' unique contribution consists of providing us with an analytical tool to understand and challenge the totality of the capitalist system. ${ }^{2}$ We can have a genuine understanding of the totality of capitalism insofar as the totality in question is understood both as a subject and an object. Thus, Lukács suggests that we cannot understand the totality of capitalism by merely looking at individual facts (e.g., how many workers were laid off, industrial accidents in Bangladesh, methods of labor 
regulation). Individual facts like that have to be understood through the tendencies that underpin and animate them. In other words, the basic methodological point of Lukács is that we cannot understand capitalist totality merely as the object of a reflection; there have to be processes that allow for the $s u b$ ject of the totality of capitalism (the animating principle of it). For both Marx and Lukács that subject of the capitalist totality is labor, since labor is the source of value and profit. Therefore, for Lukács only a class that comes into being as the subject of the process of commodification, a class that is at the source of this process of commodification, its animating principle, would be able to understand the process itself, precisely because it is the subject that makes that process. That class is the working class (the proletariat), who find themselves "directly and wholly on the side of the object" and are "an object and not an active factor in the work process" (Lukács, 1923, pp. 294-295); the proletariat is the identical subject-object of history (Westerman, 2010).

Lukács uses here a basic principle of Kantian philosophy; we can understand the things that we make, the ideas that we have, and the forms that we impose on reality. Insofar as it is the proletariat that is directly or indirectly exploited by capital, and insofar as it is the proletariat that makes reality, the proletariat can then know reality and can understand reality. Labor has the capacity to become conscious of capitalist reality, once it reaches a certain point. That "transition" in Lukács is a bit obscure, but it can be summarized as follows: when history reaches a certain point where commodification becomes the totalizing drive of society and the human being has been commodified, the workers have nothing left but the loss of their humanity. That is, the situation becomes more critical the more aggressive capitalism becomes and the more crises, "human sacrifices" and Rana Plazas it demands. Commodification that becomes absolute-that is, "inhuman objectivity" (Lukács, 1923, p. 307) - is a violation of the humanity of people; once human beings realize this they will resist commodification. Thus, commodification will drive humanity to a point where humanity can become conscious of and grasp the process of commodification.

The process of becoming conscious in Lukács should not be confused with sociological approaches, for example on middle or working-class consciousness. Following the German critical tradition, for Lukács to become conscious is in the philosophical sense of gaining awareness or gaining an insight into the nature of reality. This kind of awareness leads to an allegiance of either the position of the dominating in capitalism, the bourgeoisie, or the victim in capitalism, the proletariat. The critical point that Lukács makes in History and Class Consciousness is that awareness from the perspective of the exploited gives you an insight into how capitalism actually works and opens the door to changing the system. On the other hand, the perspective of the person who dominates and benefits from capitalism does not open up to changing the system; rather this perspective conforms to capitalism as given, natural, and evident.

Accordingly, from the perspective of the dominant in capitalism it is a consequence of the natural order of things, albeit regrettably, for people to lose their lives producing the "stuff" we need to be content; any dissenting voice that would challenge the totality of capitalism is fundamentally illegitimate. The dominant perspective has every interest to reify reality, to conceal, for example, that labor creates all value and instead portray clever entrepreneurs as the source of wealth! Reification conveniently obscures that refusing wage increases to the poorly-paid and super-exploited factory workers in Bangladesh is an economic choice of the dominant, the result of specific historical and political conditions, and not an unassailable economic reality. As such, the perspective of the dominant is notably resilient in academic works and especially in managerialist literature. Consequently, studies on every conceivable form, mechanism, process and aspect of TLR have indeed been written over the last few decades, but research focusing on pro-worker outcomes of TLR is hard to come by. This 
is a significant topic that will be analyzed further, but let us first articulate a Lukácsian-inspired perspective on TLR and raise a list of criteria that will be used to assess the effectiveness of TLR.

\section{I CRITERIA FOR EVALUATING TRANSNATIONAL LABOR REGULATION}

Here, we form a list of substantive and normative criteria for critically evaluating TLR regimes and the ways these operate in practice, as well as their outcomes (see Table 1). We commence a Lukácsian critique of TLR from the standpoint of consciousness-raising processes; how workers can become selfconscious through collective organization. Lukács' approach on the "what-needs-to-be-done" question is twofold (Lukács, 2000). On the one hand, there is class struggle and agitation against ideologies, social institutions, the education system, media, political parties, and institutions of the state that aid commodification of society and work to advance feelings of atomization and powerlessness among workers (Lukács, 2000, pp. 14-15). On the other hand, there is worker resistance over the control of their labor power. ${ }^{3}$

Consequently, our evaluation of TLR starts with a set of criteria that question how TLR regimes - and the ways these are implemented-heighten class struggle and promote working-class emancipation, including international labor solidarity and (anticapitalist) activism.

Second is the question of how TLR may reinforce worker resistance over control of labor power. Here, trade unions can be decisive in helping progressive policies that aid resistance and solidarity (Lukács, 2000, p. 15). Therefore, we seek out the emancipatory, pro-union benefits of TLR that verifiably and demonstratively allow for at least the very basic trade union freedoms; the freedom of association and the right to bargain collectively. These two sets of criteria form our list of substantive criteria for examining TLR (see Table 1).

Further, we add two more normative elements. The first is based on the observation that reification causes the focus of scholarship and research to rest on processes (that is philosophically speaking the form), and specifically processes that submit to, rather than preclude management. Such processoriented (form-focused) scholarship glorifies all bureaucratic and administrative aspects of labor regulation, but pays little attention to the social relations of production (i.e., philosophically speaking the essence) that lie beneath. Reification of scholarship and research (and the ways these are funded and assessed) actively promotes work that seeks to prove how profitable, useful, or ethically desirable for corporations certain forms of labor regulation can be. Pro-worker outcomes that would bring to the forefront conditions of employment and social relations of production in supply chains are sidelined, if not out-rightly ignored (i.e., philosophically speaking reified), as we shall give examples later. Accordingly, our first normative criterion probes TLR for accounts of social relations of production, takes a pro-worker perspective, and seeks pro-worker outcomes; specifically-and above all elseactual, verifiable, and tangible improvements in conditions of employment and positive impacts in the everyday work and life experiences of workers, as a result of a TLR intervention. Finally, the

TABLE 1 Criteria for evaluating transnational labor regulation

\begin{tabular}{|ll|}
\hline Substantive & Normative \\
\hline $\begin{array}{l}\text { Advancement of class struggle, working-class emancipation, } \\
\text { political agitation, and of international labor solidarity and } \\
\text { activism. }\end{array}$ & $\begin{array}{l}\text { Consideration for social relations of production, pro-worker } \\
\text { outcomes, and-above all—actual improvements in conditions } \\
\text { of employment (avoidance of managerialist processes). }\end{array}$ \\
$\begin{array}{l}\text { Promotion of trade unionism, freedom of association, and right } \\
\text { to collective bargaining. }\end{array}$ & $\begin{array}{l}\text { Neutralization of commodified labor regulation and } \\
\text { nullification of privatization of labor standards. }\end{array}$ \\
\hline
\end{tabular}


second normative criterion centers on the commodification of labor laws and regulation, when (see below) labor regulation itself becomes "private" (and privatized) and a business solution to be applied for achieving pro-business results. Appropriately, a critique of TLR needs to grasp the impact of commodified labor regulation and counteract the privatization of labor standards that is slowly but certainly taking place.

\section{4 | EVALUATION OF TRANSNATIONAL LABOR REGULATION}

We evaluate TLR, using the four aforementioned criteria, against an analytical framework of TLR (Tsogas, 1999, 2000). Summarized in Table 2, historical and contemporary experiences of TLR are systematically categorized along a matrix of two regulatory planes and four trade levels. The regulatory subjects of TLR are the nation-state and the company and the regulatory objects (the means) of regulation are "soft" and "hard," all congregating across four levels of trade relations: unilateral, bilateral, regional/plurilateral, and multilateral.

Here, the adopted framework has been updated by the addition of recent developments in prison labor legislation in the United States - under the unilateral level in the hard regulation plane-and the inclusion of International Framework Agreements (IFAs), under the bilateral level, and European Works Councils (EWCs), under the regional/plurilateral level in the soft regulation plane. Further, discussion of each form of TLR is carried out under the light of recent research and developments in literature.

"Hard" regulation between state actors was the first to emerge (for a historical review see Charnovitz, 1987; Hansson, 1983, pp. 11-29). Social clauses in international trade agreements condition tariff-free (or tariff reduced) access to a market for certain products to the respect for "internationally recognized" labor standards in the exporting country. Hence, our critique begins at the unilateral level where trade laws of a country contain social clauses affecting all of its trade relations. Examples include U.S. laws attempting to prohibit imports produced by child or prison labor. Recently, the Trade Facilitation and Trade Enforcement Act of 2015 amended the U.S. Tariff Act (1930) and reportedly closed a legal loophole (the "consumptive demand exception" clause) that allowed certain products made by forced or child labor into the United States, if there was not sufficient supply to meet domestic demand (Gottwald, 2016). Enforcement is applied through the U.S. Customs and Border Protection (CBP) that collects petitions from interested parties and may issue a Withhold Release Order to detain shipments of merchandise. Repeal of the "consumptive demand exception" is perceived as instrumental in enhancing CBP's ability to prevent products made with forced labor from being imported into the United States and was heralded as a "full-fledged protection of human rights in global supply chains" (Gottwald, 2016). However, when considering actual outcomes of the law, the effectiveness of this amendment is shown to be limited. In all historical and current cases, over a period of 85 years where the CBP took action, the only bans (temporary or current) that were ever

TABLE 2 An analytical model of transnational labor regulation

\begin{tabular}{|c|c|c|c|c|c|}
\hline \multicolumn{2}{|c|}{ Regulatory } & \multicolumn{4}{|c|}{ Level of supply chain and trade relations } \\
\hline Subjects & Objects & Unilateral & Bilateral & $\begin{array}{l}\text { Regional/ } \\
\text { plurilateral }\end{array}$ & Multilateral \\
\hline State & $\begin{array}{l}\text { "Hard" } \\
\text { regulation }\end{array}$ & $\begin{array}{l}\text { Child \& prison labor legislation } \\
\text { (USA) }\end{array}$ & $\begin{array}{l}\text { GSP } \\
\text { (USA, EU) }\end{array}$ & $\begin{array}{l}\text { EU } \\
\text { NAFTA }\end{array}$ & $\begin{array}{l}\text { WTO/GATT } \\
\text { ILO }\end{array}$ \\
\hline Company & $\begin{array}{l}\text { "Soft" } \\
\text { regulation }\end{array}$ & CSR/codes of conduct & $\begin{array}{l}\text { International } \\
\text { Framework } \\
\text { Agreements }\end{array}$ & $\begin{array}{l}\text { European } \\
\text { Works Councils }\end{array}$ & $\begin{array}{l}\text { UN Global } \\
\text { Compact }\end{array}$ \\
\hline
\end{tabular}


imposed were on products made by convicts in state-run institutions. Whereas forced, bonded, and child labor are still widespread in global supply chains, if no goods produced under these conditions were ever banned in the decades prior to the removal of the "consumptive demand exception," it seems unlikely that this policy change will have any impact now. Therefore, from a pro-worker viewpoint here lays a mere procedural change in law that does not aid the development of trade unions and freedom of association in exporting countries (neither in the United States), and has little scope for improvement of working conditions in supply chains.

Next, the bilateral level entails social clauses in trade agreements between one country and a number of its trading partners. The Generalized System of Preferences (GSP) of the United States and the European Union are by far the most well-known schemes with a social clause. Their labor market and labor relations' outcomes have been studied in detail (Compa \& Vogt, 2001; Frundt, 1998). It has been claimed (Tsogas, 2001, pp. 359-360) that the existence of social clauses in the U.S. GSP since 1984 has had a significant impact in the reorientation of the U.S. labor movement; it enabled the development of international labor solidarity activism in the United States during the late 1980s and throughout the 1990s on an scale previously unknown. A plethora of labor solidarity groups, human rights organizations, NGOs, church and development groups, and individual activists committed to the rights of working men and women emerged during this period increasing the space for international labor solidarity. Significantly, an enormous amount of information, advocacy, research, and publications (aided by the then expanding internet) emerged on working conditions in supply chains around the globe. Moreover, experience on how to monitor labor rights violations and enforce local labor laws in producing countries was also generated. That wealth of information instructed debates for years to come.

Nonetheless, there was no "game change" situation. Workers' rights continued to be violated with increased ferocity in developing countries as globalization deepened. Despite unsupported claims (Reinecke \& Donaghey, 2015, p. 722), TLR debates were not dominated by trade unions and any involvement of pro-worker groups did not lead to policies tuned toward pro-worker outcomes. Academic literature on TLR that appeared in large quantities during the 1990s stemmed primarily from U.S. labor law and trade policy perspectives, including international trade and human rights lawyers (Alston, 1993; Compa, 1993) and economists and trade theorists (Fields, 1990; Piore, 1990; Sengenberger, 1994). It has been claimed (Tsogas, 2001) that the implementation of GSP schemes showed that in both the United States and Europe foreign policy considerations are paramount; no country with significant economic and trade ties to the United States or the EU was ever expelled from their GSPs, regardless of how appalling their labor standards violations had been. Thus, social clauses in GSPs had mixed outcomes: increased awareness of labor standards in supply chains and their monitoring, strengthened international labor solidarity and activism originating in the United States, but had limited pro-worker outcomes in producing countries.

Next, at the regional and plurilateral level there are social clauses in regional trade agreements such as the European Union and NAFTA. Labor market outcomes of labor regulation in NAFTA and the EU have been discussed extensively in literature, whereas immense successes in the EU are not matched by experiences under NAFTA (Compa, 1995, 1997; Cook \& Katz, 1994; Elliot, 2003). We suggest that the prime reason for that disparity is the enforceability of labor standards. The EU Social Charter and the various EU Directives are legally enforceable, but nothing like that exists under NAFTA. A useful lesson in view of Brexit is that without a supranational enforcement system, reliance among signatories of a trade agreement on self-enforcement of labor laws will not "pull" upward conditions of employment; existing disparities will remain or even extended. 
Worldwide, there were 58 trade agreements that contained labor clauses, in 2013. An International Labor Organization (ILO) report, reflecting on "whether labor provisions have created more space for improving labor standards and whether the ability to implement existing labor standards has improved", quickly concluded: "it goes beyond the scope of this publication to examine these issues in detail" (ILO, 2015, p. 22). This in itself is a remarkable comment coming from the foremost world-leading authority entrusted with the promotion of international labor standards. But from our analytical viewpoint it is not inexplicable.

The ILO was set up in 1919 (in the aftermath of the Soviet revolution in Russia) to provide a solution for the 19th and early 20th century "social question"; how to dissuade working classes in developed capitalist economies from becoming radicalized and embracing revolutionary ideas. Throughout the 20th century, it was seen as an icon of welfare capitalism. With its cornerstones on class compromise, collective bargaining, and state-sponsored tripartism welfare capitalism (EspingAndersen, 1990) worked well for most part of the 20th century and brought economic and social prosperity to millions of workers in developed economies until neoliberalism started rolling back the role of the state, and with it, collective bargaining and workers' rights. Nowadays, such is the depth of reification of social relations that, even at this level of expertise, the ILO sees it as beyond its scope to provide evidence on the effectiveness of social clauses in trade agreements in improving the working lives of people, whose rights these agreements were supposedly set up to protect. Instead, we are given extensive analyses of the technicalities, procedural, and administrative aspects of the agreements.

Finally, at the multilateral level are categorized unsuccessful and now defunct efforts to include a social clause in the World Trade Organization and its predecessor, the GATT (De Wet, 1995; Leary, 1997; Wachtel, 1998; Wolffgang \& Feuerhake, 2002). The 1994 Marrakesh agreement that established the WTO excluded labor standards from its realm—seemingly once and for all—marked a watershed on the limits of "hard" regulation. In response, labor activists and NGOs drew their attention to the supply chains of transnational companies, away from the intergovernmental level of TLR that characterized GSP, NAFTA, and all state-level forms of labor regulation (French \& Wintersteen, 2009).

Consequently, at the company plane, through "soft" regulation and at the unilateral level of supply chain relations lay corporate social responsibility (CSR) inspired approaches, including voluntary corporate or industry codes of conduct, and social labeling and certification schemes (Mamic, 2004; O'Rourke, 2003; Utting, 2002). As alluded to above, the information on working conditions in supply chains around the globe that started becoming widely available during the 1990s laid the foundation for the establishment of a new breed of professional service firms; commercial organizations - acting beyond the realm of NGOs and solidarity groups - that offer "business solutions" and consultancy services on social labeling schemes, corporate codes of conduct and other forms of international social standards. Some, like the organizations behind the AA1000 and SA8000 certification schemes that emerged during that era, effectively fashioned monitoring and enforcement of labor regulation on a commercial basis, essentially commercializing_or “privatizing” (O'Rourke, 2006)—workers' rights and their enforcement (Bartley, 2003, 2007; Büthe \& Mattli, 2011). They aim to provide a ready-made and off-the-shelf approach to labor regulation, on a commercial basis. Ineffective as these for-profit schemes may be-with questionable or hardly existent (self)enforcement mechanismsthey are nonetheless being marketed as solutions to the "ineffectiveness" of hard (especially statebound) labor regulation.

But, how effective can "soft" regulation be from a pro-worker and trade union perspective? Lund-Thomsen et al. (2012, p. 1,211) empirically investigated football ball manufacturing in 
Pakistan, India, and China and found that "evidence of gains for workers from compliance with such standards and codes remains limited and patchy." Furthermore, the work of Richard Locke and his research team (Locke, 2013; Locke et al., 2009; Locke, Distelhorst, Pal, \& Samel, 2012; Locke, Kochan, Romis, \& Qin, 2007; Locke, Qin, \& Brause, 2007; Locke, Rissing, \& Pal, 2012), provided decisive insights into this question. Their findings over a ten-year period showed that "the traditional compliance model of private voluntary regulation, which sought to deter labor violations by policing and penalizing factories, as well as the alternative capability-building approach that tried to prevent violations by enabling factories to enforce labor standards on their own, both have serious limitations" (Gereffi, 2014, p. 220). Other research has come to similar conclusions, showing possible but very temporal improvements in occupational health and safety, working hours, and other outcome standards (Egels-Zandén, 2007, Frenkel, 2001). But, on the other, there has been limited impact on process rights such as freedom of association and the right to bargain collectively (Anner, 2012; Barrientos \& Smith, 2007; Wang, 2005). Worse-reflecting on the horror of Rana Plaza and similar incidents up to date-after more than a couple of decades of CSR-inspired approaches the evidencemade by the piled up bodies of buried-alive workers-suggest anything but an improvement; rather a steep and appalling regression.

Detailed critique of the provisions, workings and effectiveness of the Accord on Fire and Building Safety and the Alliance for Bangladesh Worker Safety (the NGO and corporate-led initiatives that followed Rana Plaza) shows that their ineptness is due to prevailing business-driven CSR, businessas-usual attitudes, and business models that are fundamentally based on very low-cost production and human exploitation, with little regard for human life (Centre for Policy Dialogue, 2013; Clean Clothes Campaign, 2015; Gomes, 2013; Sinkovics, Hoque, \& Sinkovics, 2016; Venkatesan, 2013; Yee, 2015).

Rana Plaza was the biggest loss of life in an industrial "accident" in recent years, and though it was responded to as appalling, it did not lead to political activism, nor calls for overthrowing capitalism, the root-cause of the disaster. Quite to the contrary, it led to the signing of an Accord (a meager glorified "gentleman's" agreement) simply on health and safety issues (not on freedom of association nor any other fundamental workers' rights) whose enforcement is highly dubious, and very much within the parameters of global capitalism (Cairola, 2015). In other words, such a grip capitalism and commodification have upon people and so reified social relations are, that this disaster did not lead to any realization for radical action, but, to the contrary, to the strengthening of pro-business and fundamentally toothless regulation.

For all terms and purposes, the old neoliberal argument that the poor cannot afford labor standards and collective bargaining rights (as well as "western style" human rights in general; see Tsogas, 1999), but only the bare minimum of health and safety rules, re-emerged in the Accord and the Alliance. And it was put into practice-in true neoliberal style-not through an effective, government-sponsored health and safety regime, but rather through an "independent," "third-party," "multi-stakeholder," (and corporate controlled) voluntary verification scheme.

The Accord/Alliance is a warning of how privatization of labor regulation may work in the future, under the "clever" disguise of a multi-stakeholder approach. Such regulation not only does not challenge the exploitation upon which fast fashion supply chains are based, but it conversely and perhaps perversely provides legitimacy to the eyes of the stakeholders involved and to the public at large. That is to say that labels and subcontractors have continued to profit from the blood and toil of their workers while claiming that they are "taking steps" or even have in place some allegedly robust system for avoiding other disasters (a claim that careful examination of implementation procedures and independent factory inspections can easily disprove). Worse, NGOs could portray such agreements 
as a success that justifies and legitimizes further their involvement in supply chain regulation and academic researchers could venture to seek for and pronounce as successful the workings of such schemes (Reinecke \& Donaghey, 2015, 2018). We call this unfortunate development in TLR as accordification and distinguish it as a symptom of reification, where meaningless processes are celebrated as positive achievements.

Further, let us move to the bilateral level of our framework, stand IFAs (also ambitiously known in the US as Global Framework Agreements, GFAs), a form of "soft" regulation negotiated between a multinational company and an international sectoral trade union federation (Riisgaard, 2005; Schömann, Sobczak, Voss, \& Wilke, 2008; Thomas, 2011). IFAs emerged in the late 1990s as the institutional trade union response to CSR. Alarmed by declining membership and encroachment of NGOs into their domain (workers' rights, labor standards, even representation), trade unions' way forward included engaging with multinationals - that is (re)gaining legitimacy (Papadakis, 2011, p. 14) in the eyes of employers - to safeguard what indeed may be perceived as obvious; respect by employers of the fundamental rights of their workforce, especially where legal protections and enforcement are lacking. IFAs were conceived at the very top of trade union bureaucratic structures and negotiated with senior executives of multinationals; they were neither product of workers' mobilization nor of trade union activism. They have attracted considerable attention in contemporary academic literature, but despite great expectations for promoting workers' rights their labor market outcomes are hard to come by. Niforou (2011) showed that IFAs are largely unenforceable across global supply chains and pleas for future research that would "provide an in-depth examination of the IFA impact" (Niforou, 2014, p. 383). Riisgaard (2005) talked about how "promising" they could be and Thomas (2011, p. 275) focused on "the capacities of the agreements to bring workers into the process of labor rights regulation," that is the "extent to [which] they constitute a shift from a protective approach to labor rights to one based on empowerment."

The closest literature has come to provide some evidence of improving conditions of employment as a result of an IFA/GFA, is with McCallum's (2013) much-celebrated work. However, a careful read of the book reveals that actual outcomes have been mixed and very short-lived (see pp. 148-149); with hardly any positive, lasting impacts that can be attributed to a GFA. Clear positive effects (meaning going beyond the signing of a trade-union recognition agreement to evidence of increased wages, better conditions, etc.) according to McCallum have been observed only in Poland, which received only negligible attention in the book (literally only a line!). But why Poland? Because, we suggest, Poland as a member of the EU (and in spite of a right-wing nationalist government in power) comes under the enabling EU regulatory framework, which in spite of its weakening in recent years, does still provide the supranational regulatory framework that can "step in" when national regulation lacks. We suggest that IFAs are fundamentally incapable to affect conditions on the ground, unless they are strongly linked with dynamic organizing campaigns, that they themselves are able to produce improved conditions and wages in depth of time. Merely signing an agreement is far from enough. Implementation is key. As McCallum (2013, p. 146) consents, the success of TLR "depends on actors enforcing local rules in disparate ways." But, has not that always be the case? Thus, beyond calming trade union anxieties about their relevance and generating a voluminous managerialist discourse (mainly on bureaucratic and administrative aspects of labor regulation) that reifies social relations and exploitation, little positive can be attributed to IFAs/GFAs, not even the ability to create organizational inroads for unions (Marzán, 2014).

Likewise, regarding EWC, located at the plurilateral level in our framework, little evidence exists of any positive effects on the employees of the companies in which they operate. Recent literature on EWCs focuses on broader labor relations' effects (Pulignano, Lucio, \& Walker, 2013), trade-union 
representativeness (Pulignano, 2005, 2006), and procedural aspects (Sydow, Fichter, Helfen, Sayim, \& Stevis, 2014); for example, the typical bureaucratic and administrative aspects of reified labor regulation, but not on demonstrating any direct positive impact for workers. This lack of proworker focus becomes even more shocking considering that a historically reoccurring theme in the broader literature on workers' participation in (management) decision making (a subset of which is EWCs) is the compulsion to provide evidence of how "useful" for management such schemes are; for example in increasing company profitability (Levine, 1990), productivity (Ben-Ner \& Jones, 1995; Doucouliagos, 1995) and employee satisfaction (Miller \& Monge, 1986). In other words, such is the absoluteness of commodified academic thinking within the reified totality that is capitalism that academic scholarship deems it worthwhile to prove the credentials of EWCs to management, but not to workers!

Finally, at the multilateral level of "soft" regulation stands the United Nations' Global Compact (UNGC) that aims to regulate the behavior of transnational corporations through the multilateral role of the UN (Bendell, 2004; Rasche, 2009; Rasche, Waddock, \& McIntosh, 2012). In practice, the completely voluntary nature of the UNGC and the lack of any oversight or implementation mechanism have given rise to new euphemism: "bluewash." Akin to our familiar greenwash, "bluewashing" assists companies to appear to be aligned with the humanitarian and peace-seeking role of the UN and through such perception of an association to receive "an informal stamp of approval and a brand spillover" that could improve corporate image, but without actually changing their business practices (Sethi \& Schepers, 2014; Wexler, 2013, p. 822).

\section{5 | CONCLUSIONS AND ISSUES FOR FURTHER RESEARCH}

History and Class Consciousness is the originating text of the entire tradition of Western Marxism. Reification has been utilized plethorically in political discussions and academic discourses in Arts and Humanities, except where it is perhaps most relevant: in the world of Work and for unearthing the social relations that underpin contemporary production in supply chains. This article aims to reverse that situation and open inroads toward further engagement with critical social theory and Marxist philosophy in particular, in the field of Labor Relations. Thus, going back to the philosophical foundations of revolutionary Marxism, we have presented a critique of TLR from an "orthodox" Marxist perspective. In doing so, we aim to update the dormant Marxist debate in Labor Relations, and ameliorate the continuing under-theorization of TLR.

Key ideas from Marx and Lukács (commodification and reification) can theoretically explain the complicity of academic scholarship and the weaknesses of government policies. They can also offer a critical standpoint that further research can emulate. That is, research that goes beyond conventional analyses of power relations between capital and labor, competition in international product and labor markets, neoliberal policies, and the power of transnational corporations, among others, searching instead for broad overarching themes and theoretical narratives; above all philosophically and politically informed research that is not hostage to managerialist narratives.

Reification fosters a form of consciousness that fails to distinguish the social relations of domination. Our purpose here was to go beyond individual explanations of why scholarly research choses not to, or is even incapable of uncovering unpalatable facts. We searched for societal and systemic reasons for why — as we observed — research and policy on TLR remain mostly blind (or indifferent) to horrific abuses, but spends relentless and seemingly senseless effort in searches for bureaucratic particulars and semantics, and accordifies regulation by hailing hollow processes (empty of positive pro-worker outcomes) as groundbreaking achievements. 
Inevitably, in this article, we may have only scratched the surface of an enormous and complicated topic. Further research needs to consider the full length of supply chains and the role of informal markets in developing countries. Apart from the "formal" and visible factories that supply directly brand labels, there are also numerous smaller factories, back-street workshops and homeworkers; the subcontractors of the formal factories. These workplaces, in spite of their significance on local economies and peoples' livelihoods, always escape TLR schemes. Either fully in the informal economy or in the shadows, by their very nature are beyond legal, regulatory, and often trade unions' reach.

Here, we have put forward a fundamental question that merits further research: what are the positive effects, if any, of TLR schemes on the conditions of employment and daily life experiences of workers in supply chains? What is the evidence of any demonstrable and verifiable such improvements, as a result of a TLR intervention? While we cannot provide a full alterative, we propose that the very least TLR schemes should do is to verifiably improve condition of employment in supply chains. We call for TLR instruments that are legally enforceable and effective, delivering positive labor standards outcomes. And scholarship should seek ways to verify any positive impacts.

\section{ENDNOTES}

\footnotetext{
${ }^{1}$ We should not confuse reification with alienation, in their Marxian contexts. The reification of relations is a consequence of commodification, but not the same as alienation. Alienation is experienced when workers have no rights of ownership over the price of their labor and indeed no rights over the form and outcome of their labor. But reification is the theory about the social expression of the expression of relations among workers.

${ }^{2}$ For an in-depth discussion of the philosophical concept of totality, see Jay, 1986 and for a review of critiques of Lukács' notion of totality, particularly those elaborated by Lyotard, Althusser, Deleuze, and others from the Italian Autonomist tradition, see Nir, 2016.

${ }^{3}$ In the confines of this article, we cannot address the significant matter of the relation between working class selfconsciousness and the role that a Revolutionary Party would play in that process (for a discussion see Westerman, 2010). Here, we discuss forms of working-class organization from a broader perspective that includes trade unions. In that respect, we admit guilty of being discerning in adopting selectively elements of Lukács' thought.
}

\section{ORCID}

George Tsogas (D) https://orcid.org/0000-0003-2080-8747

\section{REFERENCES}

Alston, P. (1993). Labor rights provisions in US trade law: ‘Aggressive unilateralism’? Human Rights Quarterly, 15(1), 1-35.

Anner, M. S. (2012). Corporate social responsibility and freedom of association rights: The precarious quest for legitimacy and control in global supply chains. Politics and Society, 40(4), 609-644. https://doi.org/10.1177/0032329212460983

Barrientos, S., \& Smith, S. (2007). Do workers benefit from ethical trade? Assessing codes of labor practice in global production systems. Third World Quarterly, 28(4), 713-729. https://doi.org/10.1080/01436590701336580

Bartley, T. (2003). Certifying forests and factories: States, social movements, and the rise of private regulation in the apparel and forest products fields. Politics and Society, 31(3), 433-464. https://doi.org/10.1177/0032329203254863

Bartley, T. (2007). Institutional emergence in an era of globalization: The rise of transnational private regulation of labor and environmental conditions. American Journal of Sociology, 113(2), 297-351. https://doi.org/10.1086/518871

Bendell, J. (2004). Flags of inconvenience? The global compact and the future of the united nations. International Centre for Corporate Social Responsibility (ICCSR), Research Paper Series, No. 22-2004, Nottingham, UK: ICCSR.

Ben-Ner, A., \& Jones, D. C. (1995). Employee participation, ownership, and productivity: A theoretical framework. Industrial Relations, 34(4), 532-554. https://doi.org/10.1111/j.1468-232X.1995.tb00387.x

Berger, P. L., \& Luckmann, T. (1971). The social construction of reality: A treatise in the sociology of knowledge. London: Penguin University Books.

Bewes, T. (2002). Reification, or, the anxiety of late capitalism. London: Verso. 
Büthe, T., \& Mattli, W. (2011). The new global rulers: The privatization of regulation in the world economy. Princeton, NJ: Princeton University Press.

Cairola, E. (2015). Back to fundamentals: Organizing, collective bargaining and promotion of a decent work framework in global supply chains. International. Journal of Labor Research, 7(1-2), 9-15.

Centre for Policy Dialogue. (2013). 100 days of Rana plaza tragedy_First independent monitoring report. A report on commitments and delivery. Dhaka, Bangladesh: Centre for Policy Dialogue.

Chari, A. (2010). Toward a political critique of reification: Lukács, Honneth and the aims of critical theory. Philosophy \& Social Criticism, 36(5), 587-606.

Charnovitz, S. (1987). The influence of international labor standards on the world trading regime. A historical overview. International Labor Review, 126(5), 565-584.

Clean Clothes Campaign (2015). Who has paid and who is dragging their heels. Retrieved from http://www.cleanclothes.org/safety/ ranaplaza/who-needs-to-pay-up

Compa, L. (1993). Labor rights and labor standards in international trade. Law and Policy in International Business, $25(1), 165-191$.

Compa, L. (1995). Going multilateral: The evolution of US hemispheric labor rights policy under GSP and NAFTA. Connecticut Journal of International Law, 10, 337-364.

Compa, L. (1997). Another look at NAFTA. Dissent, 44(1), 45-50.

Compa, L., \& Vogt, J. S. (2001). Labor rights in the generalized system of preferences: A 20-year review. Comparative Labor Law and Policy Journal, 22(2/3), 199-238.

Cook, M. L., \& Katz, H. C. (1994). Regional integration and industrial relations in North America. Ithaca: TLR Press.

Coslovsky, S. V., \& Locke, R. (2013). Parallel paths to enforcement: Private compliance, public regulation, and labor standards in the Brazilian sugar sector. Politics and Society, 41(4), 497-526.

De Wet, E. (1995). Labor standards in the globalized economy: The inclusion of a social clause in the general agreement on tariff and trade/world trade organization. Human Rights Quarterly, 17(3), 443-462.

Dehnen, V., \& Pries, L. (2014). International framework agreements as a thread in the texture of transnational labor regulation. European Journal of Industrial Relations, 20(4), 335-350.

Doucouliagos, C. (1995). Worker participation and productivity in labor-managed and participatory capitalist firms: A meta-analysis. Industrial and Labor Relations Review, 49(1), 58-77.

Egels-Zandén, N. (2007). Suppliers' compliance with MNC's codes of conduct: Behind the scenes at Chinese toy suppliers. Journal of Business Ethics, 75(1), 45-62.

Elliot, K. A. (2003). Labor standards and the free trade area of the Americas. Institute for International Economics, Working Paper 03-7. Washington, DC: Institute for International Economics.

Esping-Andersen, G. (1990). The three worlds of welfare capitalism. Cambridge, MA: Polity Press.

Fields, G. S. (1990). Labor standards, economic development, and international trade. In S. Herzenberg \& J. Perez-Lopez (Eds.), Labor standards and development in the global economy (pp. 19-34). Washington, DC: U.S. Department of Labor, Bureau of International Labor Affairs.

French, J. D., \& Wintersteen, K. (2009). Crafting an international legal regime for worker rights: Assessing the literature since the 1999 Seattle WTO Protests. International Labor and Working-Class History, 75, 145-168.

Frenkel, S. (2001). Globalization, athletic footwear commodity chains and employment relations in China. Organization Studies, 22(4), 531-562.

Frundt, H. J. (1998). Trade conditions and labor rights: US initiatives, Dominican and central American responses. Gainesville, FL: University Press of Florida.

Fryer, R. H. (1973). Redundancy, values, and public policy. Industrial Relations Journal, 4(2), 2-19.

Gereffi, G. (2014, 2013). On Richard M. Locke, The promise and limits of private power: Promoting labor standards in a global economy. In Socio-economic review (Vol. 12, pp. 219-235). New York, NY: Cambridge University Press.

Gomes, W. (2013). Reason and responsibility: The Rana plaza collapse. OpenDemocracy. Retrieved from https://www. opendemocracy.net/opensecurity/william-gomes/reason-and-responsibility-rana-plaza-collapse

Gottwald, E. (2016). Tariff Act strengthened, but will enforcement follow? International Labor Rights Forum (TLRF). Retreived from http://www.laborrights.org/blog/201602/tariff-act-strengthened-will-enforcement-follow

Habermas, J. (1984). The theory of communicative action. Vol. 1: Reason and the rationalization of society. Boston, MA: Beacon Press.

Hansson, G. (1983). Social clauses and international trade. London: Croom Helm.

Honneth, A., Butler, J., Geuss, R., Lear. J., \& Jay, M. (2008). Reification. Oxford: Oxford University Press.

Hyman, R. (1975). Industrial relations: A Marxist introduction. London: Palgrave Macmillan.

International Labor Organisation (ILO). (2015). Studies on growth with equity. Social dimensions of free trade agreements. Geneva: ILO.

Jay, M. (1986). Marxism and totality: The adventures of a concept from Lukács to Habermas. Berkley, CA: University of California Press.

Leary, V. A. (1997). The WTO and the social clause: Post-Singapore. European Journal of International Law, 8(1), 118-122.

Levine, D. I. (1990). Participation, productivity, and the firm's environment. California Management Review, 32(4), 86-100. 
Locke, R. (2013). The promise and limits of private power: Promoting labor standards in a global economy. New York, NY: Cambridge University Press.

Locke, R., Amengual, M., \& Mangla, A. (2009). Virtue out of necessity? Compliance, commitment, and the improvement of labor conditions in global supply chains. Politics and Society, 37(3), 319-351.

Locke, R., Distelhorst, G., Pal, T., \& Samel, H. M. (2012). Production goes global, standards stay local: Private regulation in the global electronics industry. MIT Political Science Department Working Paper No. 2012-1. Retreived from http://papers.ssrn.com/ sol3/papers.cfm?abstract_id=1978908

Locke, R., Kochan, T., Romis, M., \& Qin, F. (2007). Beyond corporate codes of conduct: Work organization and labor standards at Nike's suppliers. International Labor Review, 146(1-2), 21-40.

Locke, R., Qin, F., \& Brause, A. (2007). Does monitoring improve labor standards? Lessons from Nike. Industrial and Labor Relations Review, 61(1), 3-31.

Locke, R., Rissing, B. A., \& Pal, T. (2012). Complements or substitutes? Private codes, state regulation and the enforcement of labor standards in global supply chains. British Journal of Industrial Relations, 51(3), 519-552.

Lukács, G. (1923). History and class consciousness. Cambridge, MA: The MIT Press.

Lukács, G. (2000). A defense of history and class consciousness: Tailism and the dialectic. London: Verso.

Lund-Thomsen, P., Nadvi, K., Chan, A., Khara, N., \& Xue, H. (2012). Labor in global value chains: A comparative study of workers' conditions in football manufacturing in China, India and Pakistan. Development and Change, 43(6), 1211-1237.

Mamic, I. (2004). Implementing codes of conduct: How business manage social performance in global supply chains. Geneva and Sheffield: ILO and Greenleaf Publishing.

Marx, K. (1990). Capital: A critique of political economy (Vol. 1). New York, NY: Penguin.

Marzán, C. F. R. (2014). Organizing with international framework agreements. University of California Irvine Law Review, 4(2), $725-780$.

McCallum, J. (2013). Global unions, local power: The new spirit of transnational labor organizing. Ithaca, NY: ILR Press.

Miller, K. I., \& Monge, P. R. (1986). Participation, satisfaction, and productivity: A meta-analytic review. Academy of Management Journal, 29(4), 727-753.

Niforou, C. (2011). International framework agreements and industrial relations governance: Global rhetoric versus local realities. British Journal of Industrial Relations, 50(2), 352-373.

Niforou, C. (2014). International framework agreements and the democratic deficit of global labor governance. Economic and Industrial Democracy, 35(2), 367-386.

Nir, O. (2016). Lukács today: Totality, labor, and fantasies of revenge. Rethinking Marxism, 28(2), 154-170.

O'Rourke, D. (2003). Outsourcing regulation: Analyzing nongovernmental systems of labor standards and monitoring. Policy Studies Journal, 31(1), 1-29.

O'Rourke, D. (2006). Multi-stakeholder regulation: Privatizing or socializing global labor standards? World Development, 34(5), 899-918.

Papadakis, K. (2011). Shaping global industrial relations. Basingstoke: Palgrave Macmillan/ILO.

Piore, M. J. (1990). Labor standards and business strategies. In S. Herzenberg \& J. Perez-Lopez (Eds.), Labor standards and development in the global economy (pp. 35-49). Washington, DC: US Department of Labor, Bureau of International Labor Affairs.

Pulignano, V. (2005). EWCs and cross-national employee representative coordination. A case of trade union cooperation? Economic and Industrial Democracy, 26(3), 383-412.

Pulignano, V. (2006). Still 'regime competition'? Trade unions and multinational restructuring in Europe. Relations Industrielles/Industrial Relations, 61(4), 615-638.

Pulignano, V., Lucio, M. M., \& Walker, S. (2013). Globalization, restructuring and unions: Transnational co-ordination and varieties of labor engagement. Relations Industrielles/Industrial Relations, 68(2), 261-289.

Rasche, A. (2009). 'A necessary supplement': What the United Nations global compact is and is not. Business \& Society, 48(4), 511-537.

Rasche, A., Waddock, S., \& McIntosh, M. (2012). The United Nations global compact: Retrospect and prospect. Business \& Society, 52(1), 6-30.

Reichelt, H. (2005). Social reality as appearance: some notes on Marx's conception of reality. In W. Bonefeld \& K. Psychopedis (Eds.), Human Dignity. Social autonomy and the critique of capitalism: 31-67. Aldershot, England \& Burlington, VT: Ashgate Publishing.

Reinecke, J., \& Donaghey, J. (2015). After Rana Plaza: Building coalitional power for labor rights between unions and (consumption-based) social movement organizations. Organization, 22(5), 720-740.

Reinecke, J., \& Donaghey, J. (2018). When industrial democracy meets corporate social responsibility. A comparison of the Bangladesh accord and alliance as responses to the Rana Plaza disaster. British Journal of Industrial Relations, 56(1), 14-42.

Riisgaard, L. (2005). International framework agreements: A new model for securing workers rights? Industrial Relations, 44(4), 707-737.

Rodríguez-Garavito, C. A. (2005). Global governance, cross-border organizing, and labor rights: Codes of conduct and anti-sweatshop struggles in global apparel factories in Mexico and Guatemala. Politics and Society, 33(2), 203-333.

Schömann, I., Sobczak, A., Voss, E., \& Wilke, P. (2008). Codes of conduct and international framework agreements: New forms of governance at company level. Luxembourg: Publications Office of the European Union. 
Sengenberger, W. (1994). Restructuring at the global level: The role of international labor standards. In W. Sengenberger \& D. Campbell (Eds.), Creating economic opportunities: The role of labor standards in industrial restructuring (pp. 395-418). Geneva: ILO.

Sethi, P. S., \& Schepers, D. H. (2014). United Nations global compact: The promise-performance gap. Journal of Business Ethics, 122(2), 193-208.

Sinkovics, N., Hoque, S. F., \& Sinkovics, R. R. (2016). Rana plaza collapse aftermath: Are CSR compliance and auditing pressures effective? Accounting, Auditing \& Accountability Journal, 29(4), 617-649.

Sydow, J., Fichter, M., Helfen, M., Sayim, K. Z., \& Stevis, D. (2014). Implementation of global framework agreements: Towards a multi-organizational practice perspective. Transfer: European Review of Labor and Research, 20(4), 489-503.

Thomas, M. P. (2011). Global industrial relations? Framework agreements and the regulation of international labor standards. Labor Studies Journal, 36(2), 269-287.

Tsogas, G. (1999). Labor standards in international trade agreements: An assessment of the arguments. The International Journal of Human Resource Management, 10(2), 351-375. https://doi.org/10.1080/095851999340594

Tsogas, G. (2000). Labor standards in the generalized systems of preferences of the European Union and the United States. European Journal of Industrial Relations, 6(3), 349-370. https://doi.org/10.1177/095968010063006

Tsogas, G. (2001). Labor regulation in a global economy. Armonk, NY: M.E. Sharpe.

Tweedie, D. (2013). Precarious work and Australian labor norms. The Economic and Labor Relations Review, 24(3), $297-315$.

Utting, P. (2002). Voluntary approaches to corporate responsibility. Geneva: United Nations Non-Governmental Liaison Service.

Venkatesan, R. (2013). Clothing garment workers in safety: The case of Bangladesh. Economic and Political Weekly, $48(48), 13$. Retreived from http://www.epw.in/journal/2013/28/web-exclusives/clothing-garment-workers-safety-case-bangladesh.html

Wachtel, H. (1998). Labor's stake in the WTO. The American Prospect, 37, 34-38.

Wang, H. Z. (2005). Asian transnational corporations and labor rights: Vietnamese trade unions in Taiwan-invested companies. Journal of Business Ethics, 56(1), 43-53.

Westerman, R. (2010). The reification of consciousness: Husserl's phenomenology in Lukács's identical subject-object. New German Critique, 37(3), 97-130.

Wexler, L. (2013). Extralegal whitewashes. DePaul Law Review, 62(3), 817-855.

Wolffgang, M. H., \& Feuerhake, W. (2002). Core labor standards in world trade law: The necessity for incorporation of core labor standards in the World Trade Organization. Journal of World Trade, 36(5), 883-901.

Yee, A. (2015). Two years after Rana plaza, are Bangladesh's workers still at risk? The Nation. Retrieved from https://www.thenation. com/article/two-years-after-rana-plaza-are-bangladeshs-workers-still-risk/

\section{AUTHOR BIOGRAPHY}

George Tsogas has published articles and a book on transnational labor standards. His research seeks new theoretical insights on work, value, commodification and labor regulation, drawing from Marxist philosophy and critical social theory.

How to cite this article: Tsogas G. Transnational labor regulation, reification, and commodification: A critical review. Labor and Society. 2018;21:517-532. https://doi.org/10.1111/lands. $\underline{12362}$ 